\title{
Effect of targeted yield approaches on growth, yield, yield attributes and nutrient uptake in maize (Zea mays L.)-chickpea (Cicer arietinum L.) cropping sequence in UKP command area of Karnataka
}

B. V. SHREENIVAS, M. V. RAVI AND H. S. LATHA

Received : 17.02.2017; Revised : 30.04.2017; Accepted : 13.05.2017

MEMBERS OF RESEARCH FORUM:

Corresponding author :

B. V. SHREENIVAS, Department of Soil Science and Agricultural

Chemistry, University of Agricultural Sciences, RAICHUR (KARNATAKA) INDIA
Co-authors :

M.V. RAVI AND H.S. LATHA, Department of Soil Science and Agricultural Chemistry, University of Agricultural Sciences, RAICHUR (KARNATAKA) INDIA

\section{Summary}

Field experiments were conducted during Kharif and Rabi seasons of 2013-14 and 2014-15 at Agricultural Research Station, Raddewadagi, dist. Kalaburagi, University of Agricultural Sciences, Raichur, Karnataka to study the effect of targeted yield approach on growth, yield, yield attributing and nutrient uptake in maize-chickpea cropping sequence by involving SSNM, STCR targeted yield approaches. Application of nutrients through SSNM for targeted yield of $8.0 \mathrm{t} \mathrm{ha}^{-1}$ recorded significantly higher plant height $(235.23 \mathrm{~cm})$, number of leaves per plant (12.43), leaf area index (0.70), total dry matter production per plant $\left(249.88 \mathrm{~g} \mathrm{plant}^{-1}\right)$, grain yield $\left(8.62 \mathrm{t} \mathrm{ha}^{-1}\right)$, length of cob $(21.30 \mathrm{~cm})$, number of grains per cob (397.30), hundred seed weight $(31.63 \mathrm{~g})$ and uptake of nitrogen, phosphorus and potassium by maize crop as compared to other treatments except STCR through fertilizers for targeted yield of $8.0 \mathrm{t} \mathrm{ha}^{-1}$. The growth parameters of chickpea crop viz., plant height, total number of branches per plant and total dry matter production $\left(36.55 \mathrm{~cm}, 29.57\right.$ and $19.13 \mathrm{~g}$ plant $^{-1}$, respectively), yield attributes viz., seed yield and 100 seed weight (29.90 q ha-1 and $25.25 \mathrm{~g}$, respectively) and total uptake of $\mathrm{N}$, $\mathrm{P}$ and $\mathrm{K}$ was significantly higher $\left(118.25,26.63\right.$ and $102.09 \mathrm{~kg} \mathrm{ha}^{-1}$, respectively) with the residual effect of nutrients applied through SSNM approach for targeted yield of $8.0 \mathrm{t} \mathrm{ha}^{-1}$ followed by STCR approach targeted yield of $8.0 \mathrm{t} \mathrm{ha}^{-1}$ as compared to other treatments.

Key words : Maize-chickpea cropping sequence, SSNM, STCR targeted yield approaches, Growth, Yield, Yield attributes, Nutrient uptake

How to cite this article : Shreenivas, B. V., Ravi, M. V. and Latha, H. S. (2017). Effect of targeted yield approaches on growth, yield, yield attributes and nutrient uptake in maize (Zea mays L.)-chickpea (Cicer arietinum L.) cropping sequence in UKP command area of Karnataka. Asian J. Soil Sci., 12 (1) : 143-150 : DOI : 10.15740/HAS/AJSS/12.1/143-150. 